\title{
Chloroleucon chacöense (Leguminosae): A Study on Morphometry of Fruits and Seeds, Germinability and Development of Seedlings
}

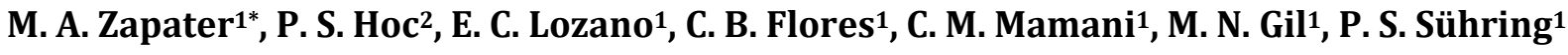 \\ ${ }^{1}$ Facultad de Ciencias Naturales, Universidad de Salta, Avenida Bolivia, Argentina \\ ${ }^{2}$ IMIBO-CONICET-F.C.E.y N.-U.B.A., Ciudad de Buenos Aires, Argentina \\ Email: *aliciazapater@yahoo.com.ar
}

How to cite this paper: Zapater, M.A., Hoc, P.S., Lozano, E.C., Flores, C.B., Mamani, C.M., Gil, M.N. and Sühring, P.S. (2016) Chloroleucon chacöense (Leguminosae): A Study on Morphometry of Fruits and Seeds, Germinability and Development of Seedlings. Open Access Library Journal, 3: e3160. http://dx.doi.org/10.4236/oalib.1103160

Received: October 21, 2016

Accepted: November 25, 2016

Published: November 28, 2016

Copyright $\odot 2016$ by authors and Open Access Library Inc.

This work is licensed under the Creative Commons Attribution International License (CC BY 4.0).

http://creativecommons.org/licenses/by/4.0/

\section{Abstract}

The dehiscent legumes of Chloroleucon chacöense (Leguminosae, Mimosoideae) are highly predated. The seeds of an intermediate type (neither orthodox, nor recalcitrant) remain in latency until the rainy station start can germinate efficiently when are imbibed $36 \mathrm{~h}$ in water before the sown, reaching similar \% than those treated with sand paper or sulphuric acid. The seeds lose their germinability when are treated with warm water, perhaps because it kills the embryo. The seedlings are developed in a high percentage (92\%) although they do not receive scarification treatments. The scarified seeds increase their weight more than the no scarified, as the Baskin Index denotes. The ANOVA and MTG show that the mechanical and chemical treatments allow the seeds to germinate till $24 \mathrm{~h}$ since the sown. The " $\mathrm{t}$ " test highlights that the no scarified seeds exhibit high difference of weight only at $24 \mathrm{~h}$ since the sown; perhaps the seeds need that lapse of time to imbibe to start the germination. Between the unhealthy seeds, those with arrested development constitute a high percentage, and perhaps some problems in the reproductive system exist. The germination is epigeal, phanerocotyledonar, with photosynthesizing cotyledons, and the seedlings have two sub-opposite protophylls (one pinnate, the other bipinnate) and two or more alternate, bipinnate eophylls. This fact implies that the classification commonly used does not cover the variability existent in the Leguminosae. Studies are needed to elucidate the origin of the low density of individuals because the species is included in the RED BOOK.

\section{Subject Areas}

Plant Science 


\section{Keywords}

Chloroleucon, Morphometry, Fruits, Seeds, Seedlings Development, RED BOOK

\section{Introduction}

The genus Chloroleucon (Benth.) Britton \& Rose comprises ten species of trees and shrubs that grow in the tropics of America, from NW Mexico, to the Antillas, southern Bolivia, part of Paraguay, dry zones of Brasil and in northern Argentina, being distributed specially in lowlands at foot of mountain chains semiarid, being part of forests with dry season, savannas and deserts, with high temperatures.

The individuals of $C$. chacöense, the "palo overo" or "palo barroso", are spiny bushes or little trees of 2 - $6 \mathrm{~m}$ height, reported for Bolivia, Paraguay and Argentina between 350 $900 \mathrm{~m}$ s.m. [1]. In Argentina, specimens has been collected in the northwestern (Jujuy and Salta) at the slopes of the Subandean mountains, growing in the ecotone between the xerophilous forest, especially the Chaco Serrano, Provincia Fitogeográfica Chaqueña [2] and the humid forest with dry season, Provincia Fitogeográfica de Las Yungas [2], as some authors at $400-500 \mathrm{~m} \mathrm{s.m.} \mathrm{[3]} \mathrm{and} \mathrm{around} \mathrm{the} 700 \mathrm{~m} \mathrm{s.m}$. as others [4] [5].

Three species of Chloroleucon are represented in northern Argentina, C. chacöense (Burkart) Barneby \& J. W. Grimes, C. tenuiflorum (Griseb.) Barneby \& J. W. Grimes and C. foliolosum (Griseb.) Barneby \& J. W. Grimes, which the last two are restricted to the first slopes of the forests of the Subandean mountains. C. chacöense is clearly differentiable from those related by its leaves, 1-2(3) pairs of pinnae and the pinnae with 1-3(4) pairs of leaflets broadly ovate; the fruits, a dehiscent legume, sub leathery and falcate (4). Recently [6] it was studied the morphometry of fruits and seeds, as well as the germinative potential and the development of seedlings of a population of $C$. tenuiflorum which grow at Salta, in the northwestern of Argentina.

C. chacöense has been reported as in danger of extinction in the RED BOOK [7]. A few years ago it was discovered a population of this species in Salta, Department Gral. Güemes, in a sheer zone of the Chaco Serrano, with a sandy reddish soil (lateritic soil), near an iron ore deposit, and perhaps a vinculation of the species with the edaphic conditions of the area exist. The population is formed by few individuals and grows mixed with a typical "quebrachal" of Schinopsis lorentzii (Anacardiaceae), and the presence of C. chacöense as fodder should be important in the area (pers. obs.). It is unknown until they present the character orthodox or recalcitrant of the seeds of $C$. chacöense as the kind of germination.

The seeds of Angiosperms can be classified, owing to their morphological and physiological characters in orthodox and recalcitrant [8]. It has been suggested that the orthodox character should be ancestral, and it has been loosed during the evolution to the recalcitrant character [8] [9]. The orthodox character constitutes clearly an adaptive advantage in xeric environments, or with a dry season, ought to the resistance to the scarce humidity; on the other hand, the recalcitrant character is clearly advantageous in 
those species that grow in humid soils or rainforests [10].

In a recent work [11], the authors described seedlings of Leguminosae in order to solve taxonomical problems, following the terminology of Recent Advances [12], distinguishing 4 categories taking into account if the germination is epigeal (phaneroepigeal, with photosynthesing cotyledons reservant or not), hypogeal (cryptohypogeal with the cotyledons reservant arising at the level of soil or below of this), placing the seedlings of Mimosoideae and Caesalpinoideae with an epigeal germination with photosynthesizing cotyledons not reservant.

The objective of this research was to analyze the production of fruits and seeds, their morphometry, and the predation before the dispersion. Also it was analyzed the germinative capacity of the seeds, the presence/absence of PY (Physical Dormancy) and the potential to develop of the seedlings in order to understand the scarce quantity of individuals in the analyzed population as well as study the possibility of regenerate under culture the quantity of individuals.

\section{Materials and Methods}

Area, collections. The study was realized in an area that belong to the Chaco Serrano, placed in Yaquiasmé, Department of General Güemes, in the center-west of Salta, Argentina, the locality of the typus speciei. The area is in the Subcuenca Mojotoro-Lavayén. The weather is warm, tropical with dry season, the medium temperature is $24^{\circ} \mathrm{C}$ during December-January, and $12^{\circ} \mathrm{C}$ during July; the annual rainfall is approximately 600 - $700 \mathrm{~mm}$. The population grows in a "Quebrachal" of Schinopsis lorentzii (Anacardiaceae) community, whose trees are chopped down for use its wood; with this cut down, fall the individuals of $C$. chacöense too. The population is restricted to lateritic soils strongly developed (Yaquiasmé soils), reddish Brown when are dry and red when are moist; the soil profile is A-B2-B3-C1-C2-C3, with moderately coarse texture in the surface $(\mathrm{FA})$, fine $(\mathrm{Fa})$ in the horizon $\mathrm{B} 2(7-33 \mathrm{~cm})$ and FA further; structure with sub-angular blocks medium to stronger; $\mathrm{pH} 6.6$ in the surface, 7.6 deeper [13].

Many field works were made between March and May of 2013-2015, in order to identify and select trees with fruits, until it was found a scarce quantity of fruits in each selected tree. From 10 trees it was collected 17 fruits for tree, almost dehiscent. It was observed a high predation made by birds in the fruits both immature and mature. The collected fruits were previously classified as healthy and predated, also in this category it were differentiated the fruits eaten, perforated or both. Any the selected especímenes studied were: ARGENTINA. Salta. Dpto. Gral. Güemes, Ruta de Güemes a El Algarrobal y Quisto, a $25 \mathrm{~km}$ del ingreso, zona de suelos arenosos rojos. fl. 24.62859S/64.82909W, 7-X-2012, Zapater \& Lozano 3094 (MCNS). Yaquiasmé, pasando el río y después del primer puente. fr. 24.62509S/64.81839W. 2-III-2013. Zapater \& Lozano 4300 (MCNS).

Methods. It was performed the description and morphometry of 65 fruits and 50 seeds, recording length and wide with a millimeter rule, thickness using a caliber in the medium zone of the fruits and seeds, and the weight was measured using a precision scale in gr. It was registered the number of seeds/fruit, which then were classified in 
healthy and unhealthy (destroyed, perforated, eaten, whitish, blackish, distorted, aborted or with arrested development). Of each dimension it is expressed the mean, if extreme values exist, are quoted between brackets.

It were calculated the $\%$ of healthy of fruits and seeds. It were established the correlation between the number of seeds vs. the dimensions of the fruits.

It was determined the presence of PY, in order to carry on this experience, Petri dishes were prepared with cotton and filter paper embedded in water, in those dishes were disposed 25 seeds without scarification and 25 with scarification (humid sandpaper). Before the sown, each seed was marked and weighted on a precision scale, and then the Petri dishes were placed in germination chambers. Every 2 hours during 12 hours it was recorded the weight of each sown seed, later at 24 hours. At 48 hours all the scarified seeds germinated, as well as most of the no scarified, their weight was not measured. With these data the IRP [14] was calculated applying the formula FW - IW/ IW $\times 100=$ IRP.

Taking into account the irregular behavior of the no scarified seeds, 20 of them were sown in Petri dishes, and 4 repetitions with different treatments, the seeds were incubated in chambers at $25^{\circ} \mathrm{C}$ with a photoperiod of $12 / 12 \mathrm{~h}$ (Table 1 ).

To find the best rank obtained by imbibitions in which the seeds should start the germination it were calculated the average and standard deviation and the " $\mathrm{t}$ " test of Student was performed [15].

It were calculated the proportion of germinated seeds using different pretreatments and the Average velocity of germination (MTG) using ANOVA [16]. With all the results the graphics were carried out. It was calculated:

Values of velocity of germination for each treatment (MTG), being:

MTG = Sumatory $(\mathrm{D} \times \mathrm{n}) /$ Sumatory $\mathrm{n}[17]$ were:

$\mathrm{n}=\mathrm{n}^{\circ}$ of seeds that germinated in the day $\mathrm{D}$.

$\mathrm{D}=\mathrm{n}^{\circ}$ of days since the start of the test of germination.

In Petri dishes with 4 repetitions and 20 seeds in each one, incubation in a germination chamber at $26^{\circ} \mathrm{C}$ and photoperiod constant (12/12 h), 6 pretreatments, including the control, were done.

An experience to evaluate the development of the seedlings during 25 - 30 days was done. It were taken 5 seeds without treatment, disinfected with sodium hypochlorite at

Table 1. Pretreatments applied for the seeds germination.

\begin{tabular}{ccc}
\hline Treatment 1 & control (without treatment) & -- \\
Treatment 2 & Leaching with cold water & $36 \mathrm{~h}$ \\
Treatment 3 & Scarifying with sand paper $120 \mathrm{~mm}$ & --- \\
Treatment 4 & Immersion in $80^{\circ} \mathrm{C}$ water, gradual cooling imbibition & $24 \mathrm{~h}$ \\
Treatment 5 & Immersion in sulphuric acid $98 \%$ & $5 \mathrm{~min}$. \\
Treatment 6 & Immersion in sulphuric acid $98 \%$ & $15 \mathrm{~min}$. \\
\hline
\end{tabular}


$50 \%$, they were sown in 10 pots filled with telgopor balls and humus, adding an antifungal in the irrigation water (Honglex of Gleba, composition: carbendazim (2-metoxicarbamoil-bencimidazol) $50 \mathrm{~g}$, dosis $2.5 \mathrm{cc}$ in 1liter of water). It was prepared a repetition in other 10 pots to take the seedlings and describe them. The irrigation was uniform with equal volume of distilled water, each pot was covered with a large and transparent bag hermetically closed that should allow the normal development of the seedlings. The pots were placed in a germination chamber at $26^{\circ} \mathrm{C}$ and a photoperiod $12 / 12$ h. The records of emergency and development were performed at 9, 11, 14, 17 and 25 days since the sown. To carry on the morphologic description of the different stages of development the seedlings were removed of the repetitions pots and after the observation, were placed in glasses with alcohol $80 \%$. The descriptions were made using a stereomicroscope.

\section{Results}

Quantity of mature fruits and health status. The total of mature fruits studied were 177 , less than the half (39\%) were healthy, while the $61 \%$ were predated, of them the $32 \%$ were attacked by birds and the remaining $43 \%$ were attacked by bruchids. If a plant has 17 - 18 mature fruits, only 6 - 7 of them should be intact and all their seeds available to germinate once they were dispersed, this means that a poor offer of recruiting possibilities exist (Table 2).

\subsection{Morphometry of Fruits and Seeds}

The dehiscent legumes have $11.05(6.5-14) \mathrm{cm}$ long. $\times 1.95(1.2-2.3) \mathrm{cm}$ wide, falcate, with undulated sutural margin, apex briefly recurve-acuminated, leathery, reddishbrown. Seeds have $5.5-8 \mathrm{~mm}$ long $\times 4-7 \mathrm{~mm}$ wide $\times 1.27-2.53 \mathrm{~mm}$ thick. In contour have wide elliptic or circular, hilar extreme sub-obtuse, yellowish-brown, integument osseous, line fissure open to the hilum. The cotyledons are sagittated, covering incompletely the root.

Correlation $n^{\circ}$ of seeds vs. dimensions of the fruit:

The index of correlation show that the number of seeds in a fruit is directly proportional to the wide of it $(r=0.84)$; as longer the fruit is, more number of seeds contain (Figures 1-4; Table 3 and Table 4).

Table 2. Health of the fruit.

\begin{tabular}{ccc}
\hline Health of the fruit & Number of fruits & Percent \\
\hline Healthy & 69 & 39 \\
Eaten & 32 & 18 \\
Perforated by bruchids & 51 & 29 \\
Eaten and perforated & 25 & 14 \\
Total & 177 & \\
\hline
\end{tabular}


Table 3. Dimensions of the fruits and number of seeds.

\begin{tabular}{cccccc}
\hline & Length $(\mathrm{cm})$ & Wide $(\mathrm{cm})$ & $\begin{array}{c}\text { Thickness } \\
(\mathrm{mm})\end{array}$ & Weight (gr) & $\mathrm{N}^{\bullet}$ of seeds \\
\hline $\begin{array}{c}\text { Mean } \\
\mathrm{n}^{\bullet} \text { of } \\
\text { sample }\end{array}$ & 11.05 & 1.95 & 2.64 & 0.56443939 & 6.10606061 \\
$\delta$ & 66 & 62 & 66 & 66 & 66 \\
\hline
\end{tabular}

Table 4. Dimensions of the seeds.

\begin{tabular}{ccccc}
\hline $\mathrm{N}^{\bullet}$ & Length $(\mathrm{mm})$ & Wide $(\mathrm{mm})$ & Thickness $(\mathrm{mm})$ & Weight (gr) \\
\hline Mean & 6.82 & 5.40 & 1.890 & 0.0789 \\
$\delta$ & 0.079 & 0.061 & 0.266 & 0.005 \\
$\mathrm{~N}^{\bullet}$ samples & 50 & 50 & 50 & 50 \\
\hline
\end{tabular}

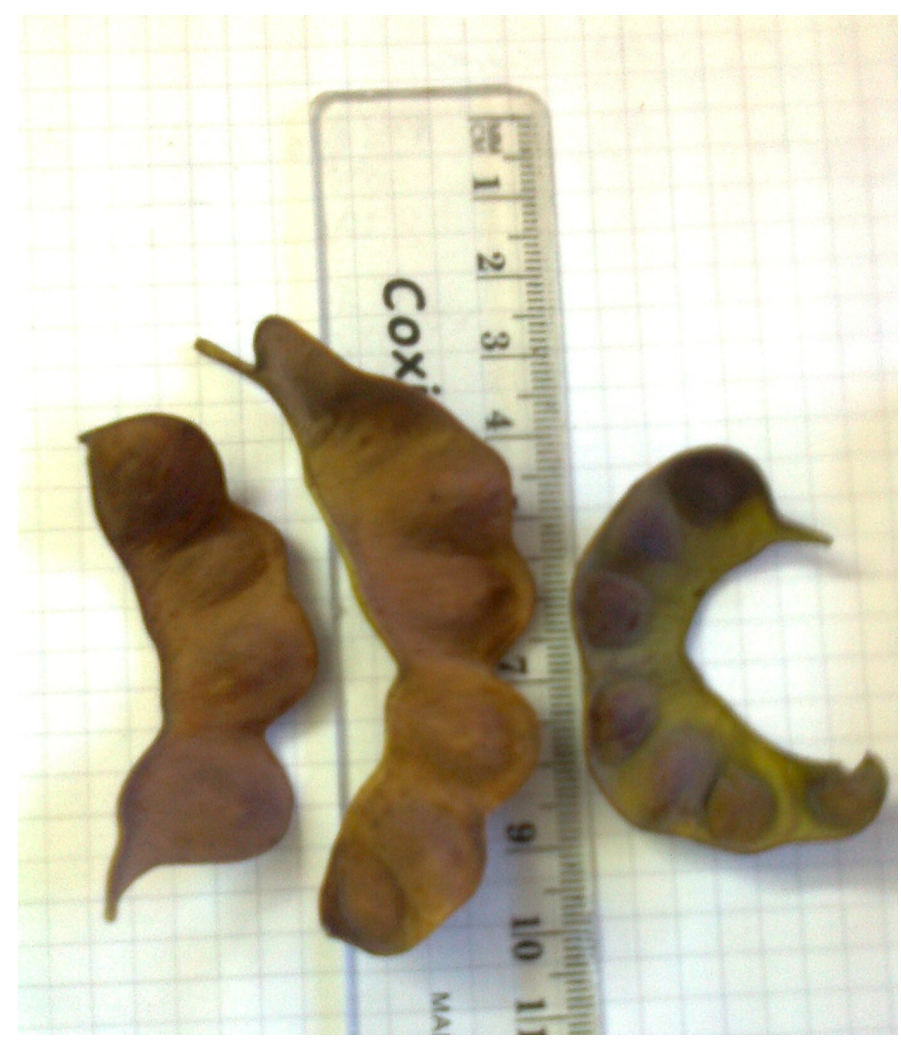

Figure 1. Three mature fruits.

\subsection{Imbibition Treatment}

The results of the " $\mathrm{t}$ " test between the means are exposed in Table 5 and Table 6, and in Figure 5 and Figure 6. The results of the imbibition test allow concluding that between the two first hours, the seeds start to increase their weight quickly and approximately after 24 hours all the seeds had complete the imbibition. 


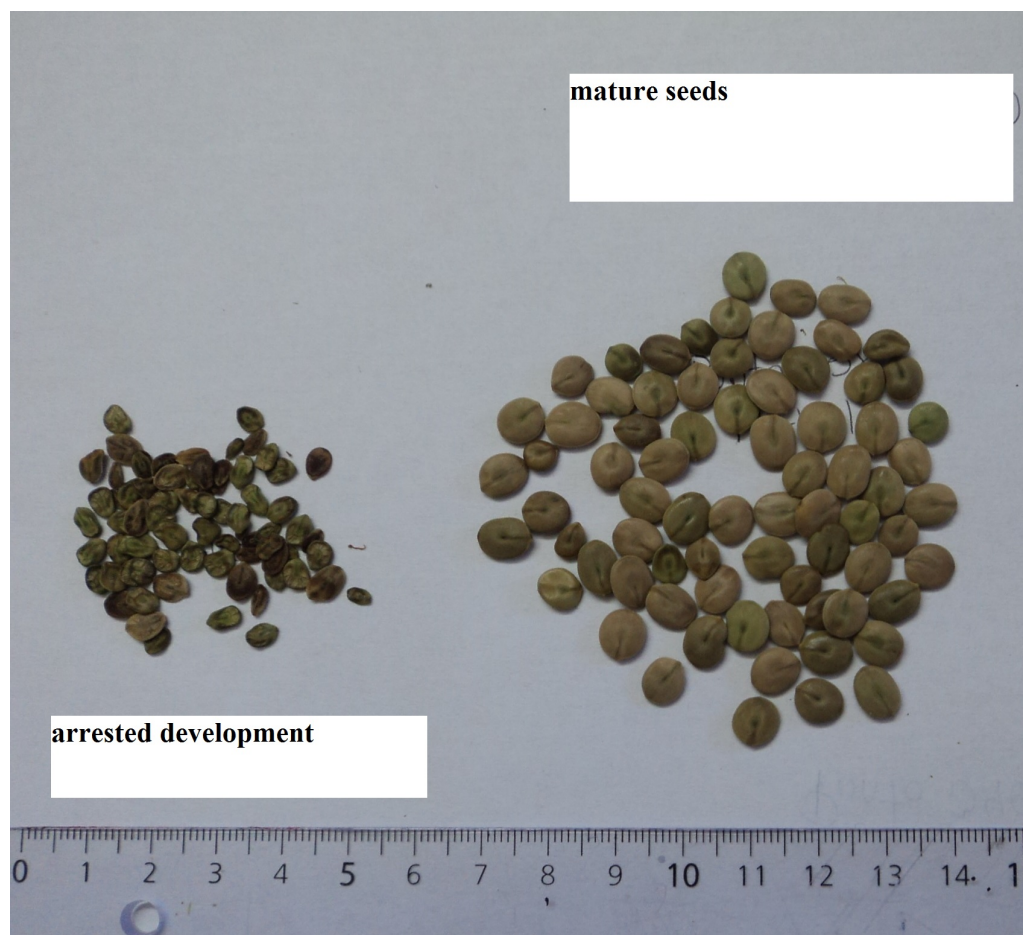

Figure 2. Mature seeds and with arrested development.

\section{Dimensions of the fruits and number of seeds}

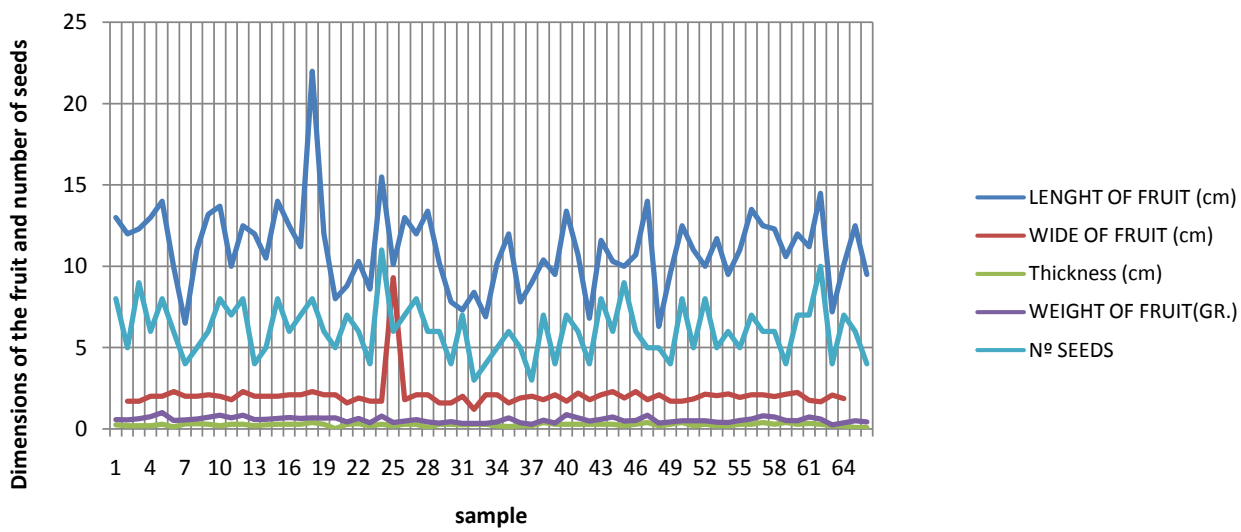

Figure 3. Correlation between the dimensions of the fruit and the number of seeds.

Only the scarified seeds which were imbibed during 2 hours exhibited significant differences with respect to those imbibed during 6 and $8 \mathrm{~h}$. Conversely, the majority of the not scarified seeds exhibited significant differences with respect to those imbibed during 24 hours, with the exception of those imbibed during 2 hours ( $\mathrm{p}=0.005$ for " $\mathrm{t}$ "). Besides, the not scarified seeds and not imbibed $(0 \mathrm{~h})$ exhibited significant differences with those imbibed during 10 and $12 \mathrm{~h}$ too.

Evolution of seminal weight until $24 \mathrm{~h}$ of imbibition (Table 7).

Index of Baskin (Table 8 and Table 9).

Two peaks of weight increase can be observed, one at 4 hours and the other at $24 \mathrm{~h}$ 


\section{Dimensions of seeds in $\mathrm{mm}$ or $\mathrm{gr}$}

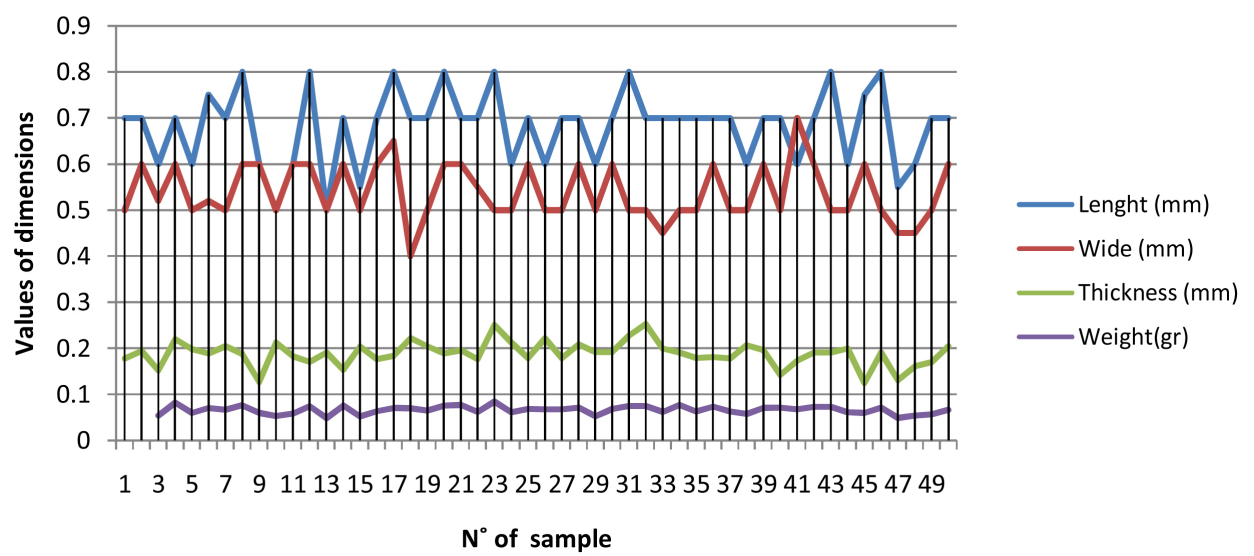

Figure 4. Dimensions of seeds. The length and the wide are the most important dimensions in the seeds, the weight is bit variable.

\section{Imbibition after scarification}

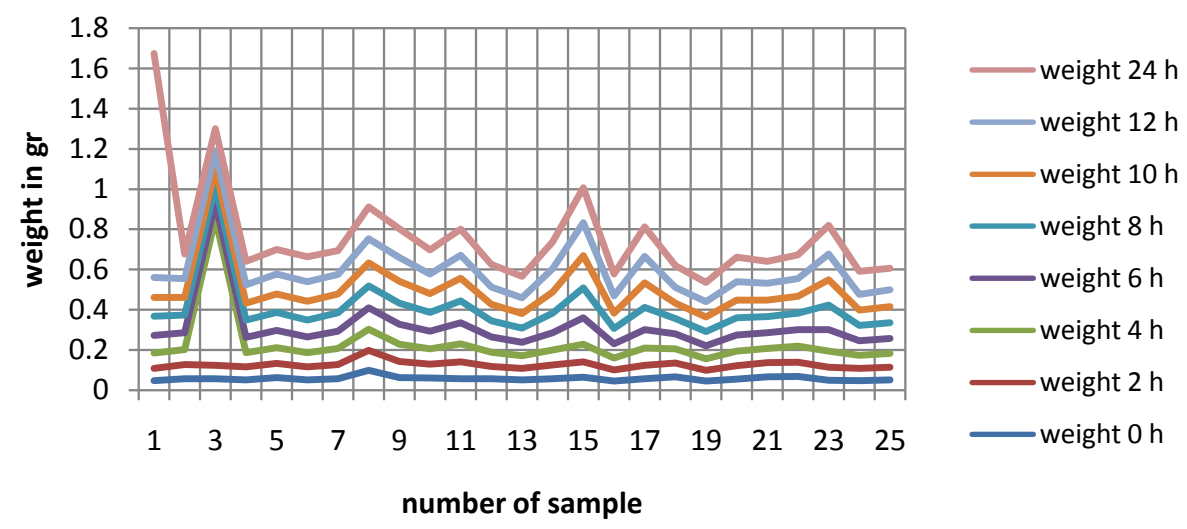

Figure 5. Imbibition after scarification. Most of the samples increase their weight a few hours after the treatment start.

\section{Seeds without scarification}
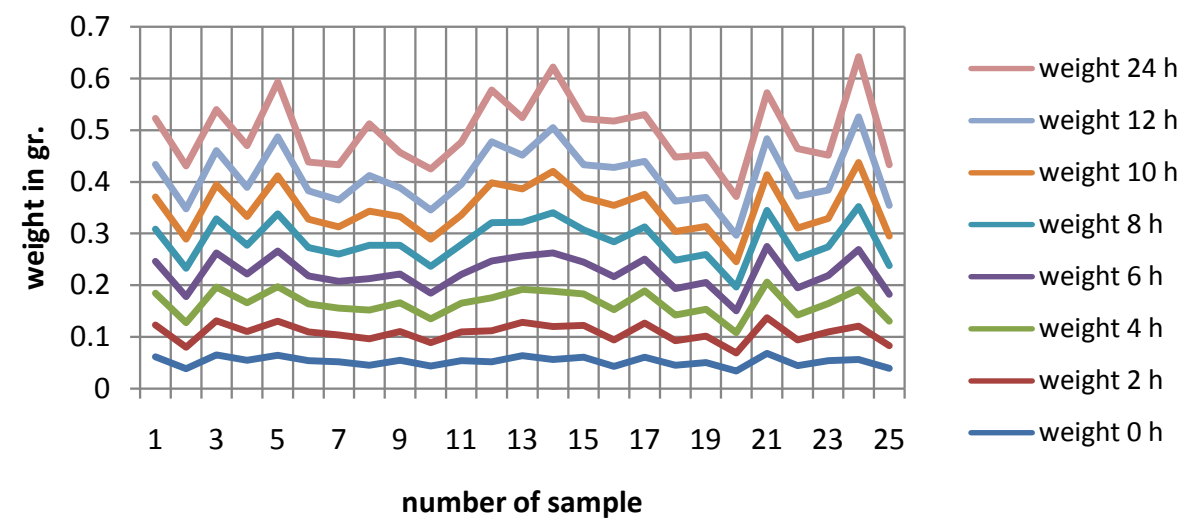

Figure 6. Imbibition without scarification. 
Table 5. Imbibition after scarification.

\begin{tabular}{|c|c|c|c|c|c|c|c|}
\hline & $\begin{array}{c}\text { Weight } \\
2 \mathrm{~h}\end{array}$ & $\begin{array}{c}\text { Weight } 4 \\
\text { h }\end{array}$ & $\begin{array}{c}\text { Weight } \\
6 \mathrm{~h}\end{array}$ & $\begin{array}{c}\text { Weight } \\
8 \mathrm{~h}\end{array}$ & $\begin{array}{c}\text { Weight } \\
10 \mathrm{~h}\end{array}$ & $\begin{array}{c}\text { Weight } \\
12 \mathrm{~h}\end{array}$ & $\begin{array}{c}\text { Weight } \\
24 \mathrm{~h}\end{array}$ \\
\hline Weight $0 \mathrm{~h}$ & 0.86 & 1.4 & 0.19 & 2.2 & 0.18 & 2.33333 & 0.49 \\
\hline Weight $2 \mathrm{~h}$ & & 1 & $3.3333\left(^{*}\right)$ & $4.44\left(^{*}\right)$ & 0.14 & 0.16 & 0.43 \\
\hline Weight $4 \mathrm{~h}$ & & & 0.66 & 0.33 & 0.05 & 0.002 & 0.21 \\
\hline Weight $6 \mathrm{~h}$ & & & & 2 & 0.53 & 0.077 & 0.38 \\
\hline Weight $8 \mathrm{~h}$ & & & & & 0.05 & 0.044 & 0.34 \\
\hline Weight $10 \mathrm{~h}$ & & & & & & 0.02 & 0.28 \\
\hline Weight $12 \mathrm{~h}$ & & & & & & & 0.22 \\
\hline
\end{tabular}

Obs.: value obtained of $v=49 ; \mathrm{p}=0.005$ for " $\mathrm{t}$ " with $v=49$, value of " $\mathrm{t}$ " from tables: 2.68. ${ }^{*}$ ) difference significant.

Table 6. Imbibition without scarification.

\begin{tabular}{|c|c|c|c|c|c|c|c|}
\hline & $\begin{array}{c}\text { Weight } \\
2 \mathrm{~h}\end{array}$ & $\begin{array}{c}\text { Weight } \\
4 \mathrm{~h}\end{array}$ & $\begin{array}{c}\text { Weight } \\
6 \mathrm{~h}\end{array}$ & $\begin{array}{c}\text { Weight } \\
8 \mathrm{~h}\end{array}$ & $\begin{array}{c}\text { Weight } \\
10 \mathrm{~h}\end{array}$ & $\begin{array}{c}\text { Weight } \\
12 \mathrm{~h}\end{array}$ & $\begin{array}{c}\text { Weight } \\
24 \mathrm{~h}\end{array}$ \\
\hline Weight $0 \mathrm{~h}$ & 0.18 & 1.6666 & 2.33 & 2.66 & $3.3333\left(^{*}\right)$ & $4(*)$ & $8.5\left(^{*}\right)$ \\
\hline Weight $2 \mathrm{~h}$ & & 0.06 & 0.18 & 0.41 & 0.41 & 0.47 & 1.72 \\
\hline Weight $4 \mathrm{~h}$ & & & 0.6 & 1.33 & 1.811111 & 2.12 & $7.25\left(^{*}\right)$ \\
\hline Weight $6 \mathrm{~h}$ & & & & 0.83 & 1.25 & 1.66 & $6.75\left(^{*}\right)$ \\
\hline Weight $8 \mathrm{~h}$ & & & & & 0.42 & 0.8333 & $6.25\left(^{*}\right)$ \\
\hline Weight $10 \mathrm{~h}$ & & & & & & 0.83333 & $6(*)$ \\
\hline Weight $12 \mathrm{~h}$ & & & & & & & $5.5\left(^{*}\right)$ \\
\hline
\end{tabular}

since the seeds were sown, it can be concluded that since the first hours of development of seedlings evolves quickly. All the seeds germinated after 48 hours.

It can be concluded that the peak of imbibitions without scarification is reached after $24 \mathrm{~h}$ since the sown was made. Many seeds germinated after 24 hours and during the lapse of $24-48 \mathrm{~h}$.

\subsection{Healthy of Seeds}

It is relevant to analyze the high \% of the aborted seeds and those with arrested development. The analysis of Table 10 and Figure 7, allow to conclude that the healthy seeds is superior than the unhealthy, besides, between the last category it can be seen that the seeds with development problems are more represented than the rest. Perhaps some problems in the reproductive system exist.

Germinative answer to different pretreatments (Table 11 and Figure 8).

According to the ANOVA differences between treatments in the average of germinated seeds exist $(\mathrm{F}=93.92 ; \mathrm{p}<0.0001)$. According to the multiple comparison tests of means DGC, the treatments 2, 3, 5 and 6 have the same values of percent of germination 
Table 7. Evolution of weight after 24 hours in those embedded seeds.

\begin{tabular}{|c|c|c|c|c|c|c|c|c|}
\hline & $\begin{array}{c}\text { Weight } \\
0 \mathrm{~h}\end{array}$ & $\begin{array}{c}\text { Weight } \\
2 \mathrm{~h}\end{array}$ & $\begin{array}{c}\text { Weight } \\
4 \mathrm{~h}\end{array}$ & $\begin{array}{c}\text { Weight } \\
6 \mathrm{~h}\end{array}$ & $\begin{array}{c}\text { Weight } \\
8 \mathrm{~h}\end{array}$ & $\begin{array}{c}\text { Weight } \\
10 \mathrm{~h}\end{array}$ & $\begin{array}{c}\text { Weight } \\
12 \mathrm{~h}\end{array}$ & $\begin{array}{c}\text { Weight } \\
24 \mathrm{~h}\end{array}$ \\
\hline & 0.048 & 0.06 & 0.0773 & 0.0881 & 0.094 & 0.095 & 0.0994 & 1.1127 \\
\hline & 0.0566 & 0.0707 & 0.0756 & 0.0831 & 0.0872 & 0.0897 & 0.0925 & 0.1213 \\
\hline & 0.057 & 0.0669 & 0.73 & 0.0791 & 0.0839 & 0.0854 & 0.0883 & 0.1112 \\
\hline & 0.0513 & 0.0639 & 0.0723 & 0.0767 & 0.0842 & 0.0858 & 0.09 & 0.1167 \\
\hline & 0.0623 & 0.0707 & 0.0786 & 0.086 & 0.0898 & 0.0927 & 0.0975 & 0.1228 \\
\hline & 0.0519 & 0.0635 & 0.0723 & 0.0776 & 0.0842 & 0.0932 & 0.0975 & 0.1239 \\
\hline & 0.0578 & 0.0701 & 0.0811 & 0.0855 & 0.0913 & 0.0934 & 0.098 & 0.1184 \\
\hline & 0.0989 & 0.1004 & 0.1046 & 0.1062 & 0.1084 & 0.115 & 0.1208 & 0.1571 \\
\hline & 0.0634 & 0.0799 & 0.0858 & 0.0989 & 0.105 & 0.1102 & 0.1165 & 0.1433 \\
\hline & 0.061 & 0.068 & 0.0777 & 0.0881 & 0.0933 & 0.0941 & 0.0971 & 0.1199 \\
\hline & 0.0578 & 0.0829 & 0.09 & 0.1045 & 0.1098 & 0.1124 & 0.1146 & 0.1297 \\
\hline & 0.0575 & 0.06 & 0.0725 & 0.0765 & 0.0795 & 0.0814 & 0.0857 & 0.1122 \\
\hline & 0.0504 & 0.0582 & 0.0635 & 0.0672 & 0.0706 & 0.0729 & 0.0781 & 0.1068 \\
\hline & 0.0568 & 0.068 & 0.0766 & 0.0856 & 0.097 & 0.1054 & 0.1162 & 0.1338 \\
\hline & 0.0638 & 0.0768 & 0.0895 & 0.131 & 0.1483 & 0.1599 & 0.1656 & 0.1722 \\
\hline & 0.0456 & 0.0541 & 0.061 & 0.0708 & 0.075 & 0.077 & 0.0854 & 0.1101 \\
\hline & 0.0576 & 0.0668 & 0.0853 & 0.0916 & 0.1114 & 0.1219 & 0.1322 & 0.146 \\
\hline & 0.0663 & 0.068 & 0.072 & 0.0738 & 0.0761 & 0.0771 & 0.0786 & 0.1091 \\
\hline & 0.0455 & 0.0529 & 0.0588 & 0.0645 & 0.0703 & 0.0732 & 0.076 & 0.0954 \\
\hline & 0.0556 & 0.0653 & 0.0736 & 0.0812 & 0.0858 & 0.0874 & 0.0911 & 0.1224 \\
\hline & 0.0671 & 0.0692 & 0.0726 & 0.077 & 0.0811 & 0.0821 & 0.0842 & 0.1087 \\
\hline & 0.0679 & 0.0712 & 0.0802 & 0.0817 & 0.0833 & 0.0842 & 0.0862 & 0.1183 \\
\hline & 0.0502 & 0.0642 & 0.0815 & 0.1054 & 0.1223 & 0.1258 & 0.1276 & 0.1439 \\
\hline & 0.0467 & 0.0611 & 0.0665 & 0.0723 & 0.0751 & 0.0769 & 0.0795 & 0.1143 \\
\hline & 0.0509 & 0.0639 & 0.0686 & 0.0737 & 0.0788 & 0.0805 & 0.0844 & 0.106 \\
\hline Mean & 0.05286 & 0.106453846 & 0.05696 & 0.11404615 & 0.1174 & 0.06228 & 0.063808 & 0.085868 \\
\hline Sample & 25 & 25 & 25 & 25 & 25 & 25 & 25 & 25 \\
\hline$\delta$ & 5.42 & 0.02 & 0.00008 & 0.05 & 0.005 & 0.003 & 0.002 & 0.023 \\
\hline
\end{tabular}

Table 8. Index of Baskin for scarified seeds.

\begin{tabular}{ccccccccc}
\hline $\begin{array}{c}\text { Weight } \\
0 \mathrm{~h}\end{array}$ & $\begin{array}{c}\text { Weight } \\
\mathbf{2 h}\end{array}$ & $\begin{array}{c}\text { Weight } \\
\mathbf{4 h}\end{array}$ & $\begin{array}{c}\text { Weight } \\
\mathbf{6 h}\end{array}$ & $\begin{array}{c}\text { Weight } \\
8 \mathrm{~h}\end{array}$ & $\begin{array}{c}\text { Weight } \\
10 \mathrm{~h}\end{array}$ & $\begin{array}{c}\text { Weight } \\
12 \mathrm{~h}\end{array}$ & $\begin{array}{c}\text { Weight } \\
24 \mathrm{~h}\end{array}$ \\
\hline 0.057916 & 0.068 & 0.1 & 0.09 & 0.09 & 0.094 & 0.099 & 0.16 & \\
----- & $13.3 \%$ & $66.7 \%$ & $50 \%$ & $50 \%$ & $56.7 \%$ & $65 \%$ & $166.7 \%$ & IRP \\
\hline
\end{tabular}


Table 9. Index of Baskin for seeds without scarification.

\begin{tabular}{ccccccccc}
\hline $\begin{array}{c}\text { Weight } \\
\mathbf{0} \mathrm{h}\end{array}$ & $\begin{array}{c}\text { Weight } \\
\mathbf{2 h}\end{array}$ & $\begin{array}{c}\text { Weight } \\
\mathbf{4 h}\end{array}$ & $\begin{array}{c}\text { Weight } \\
\mathbf{6 h}\end{array}$ & $\begin{array}{c}\text { Weight } \\
\mathbf{8 h}\end{array}$ & $\begin{array}{c}\text { Weight } \\
10 \mathrm{~h}\end{array}$ & $\begin{array}{c}\text { Weight } \\
12 \mathrm{~h}\end{array}$ & $\begin{array}{c}\text { Weight } \\
24 \mathrm{~h}\end{array}$ \\
\hline 0.05286 & 0.055356 & 0.05696 & 0.059304 & 0.061048 & 0.06228 & 0.063808 & 0.085868 & \\
----- & $4.72 \%$ & $7.76 \%$ & $12.19 \%$ & $15.49 \%$ & $17.82 \%$ & $20.71 \%$ & $62.44 \%$ & IRP \\
\hline
\end{tabular}

Table 10. Healthy vs. Unhealthy seeds.

\begin{tabular}{cccccccccc}
\hline $\begin{array}{c}\text { Healthy } \\
\text { seeds }\end{array}$ & \multicolumn{1}{c}{ Unhealthy seeds } & & & \\
\hline \\
Total & Total & Destroyed & Perforated & Eaten & Witish* & Black & Distorted & Aborted & $\begin{array}{c}\text { Arrested } \\
\text { Development }\end{array}$ \\
\hline 334 & 188 & 0 & 8 & 10 & 2 & 0 & 6 & 18 & 144 \\
$100 \%$ & $100 \%$ & $0 \%$ & $11.59 \%$ & $14.50 \%$ & $2.89 \%$ & $0 \%$ & $8.69 \%$ & $26.10 \%$ & $76.60 \%$ \\
\hline
\end{tabular}

Table 11. Germinated seeds proportion.

\begin{tabular}{cccccc}
\hline Treatment & Means & n & E.E. & & \\
\hline 5 & 1.57 & 4 & 0.07 & A & \\
3 & 1.57 & 4 & 0.07 & A & \\
2 & 1.57 & 4 & 0.07 & A & \\
6 & 1.49 & 4 & 0.07 & A & \\
1 & 1.21 & 4 & 0.07 & & B \\
4 & 0.90 & 4 & 0.07 & & \\
\hline
\end{tabular}

Means with a letter in common have not significant differences $(\mathrm{p} \leq 0.05)$.

\section{Healthy vs. Unhealthy seeds}

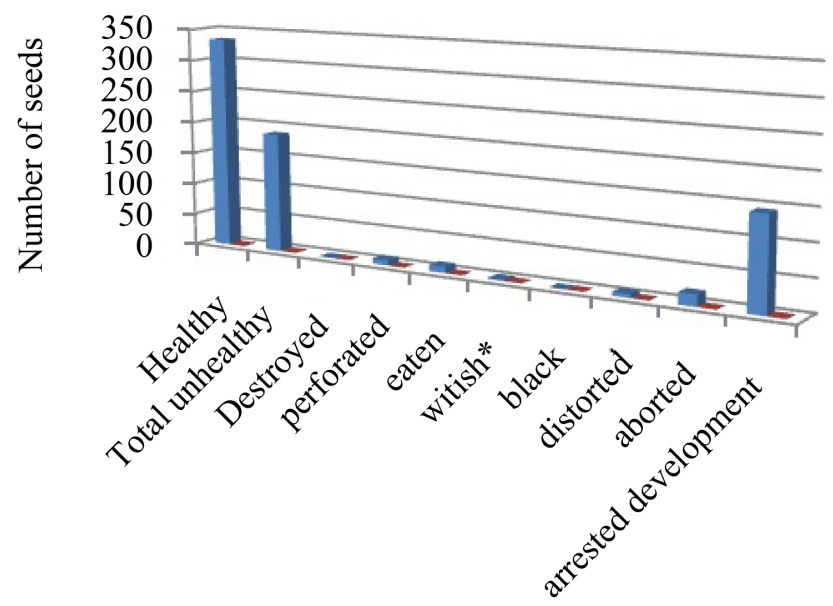

Series 1

Series 2

Figure 7. Number of healthy and unhealthy seeds. 


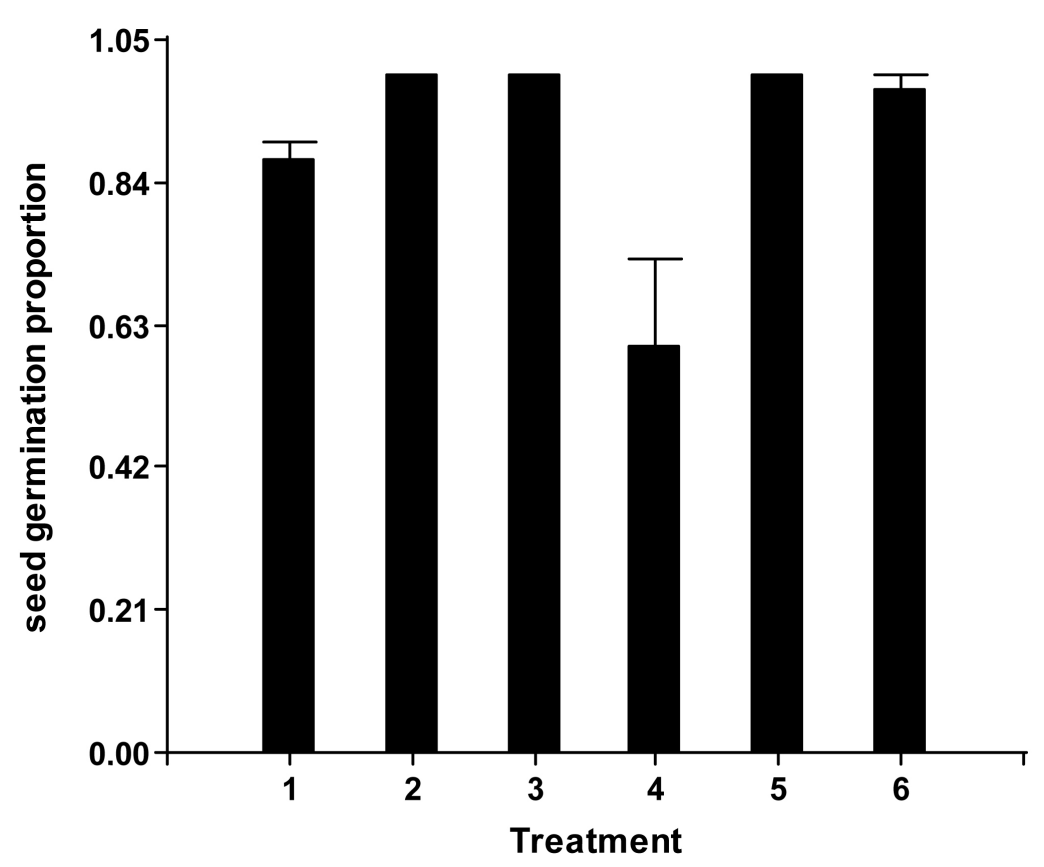

Figure 8. ANOVA of seeds germination proportion.

and higher than the rest, in consequence, the leaching during $36 \mathrm{~h}$, the scarifying with sandpaper and the scarifying with sulphuric acid during $5^{\prime}$ and $15^{\prime}$ produce the same effect. The treatment 4 , with an immersion in $80^{\circ} \mathrm{C}$ water and a following cooling, is the only that have a significantly lesser $\%$ of germination; perhaps the high temperature should affected the embryos. The control reached a high \% of germination (85\%).

According to ANOVA it was not recorded significant differences in the mean of MTG between treatments $(F=2.32 ; \mathrm{p}=0.0862)$. The seeds start the germination before the $48 \mathrm{~h}$ in all the cases (Table 12 and Figure 9).

\subsection{Development of the Seedlings}

Since the beginning of germination, and during 25 days, it was recorded the development of the seedlings, it start with the emergence of the primary root, generally in $48 \mathrm{~h}$, then, the hypocotyls elongates exposing the cotyledons gradually until 17 past the sown. The germination is epigeal. A days after, the two protophylls, opposite, star to develop an elongate until the $11^{\circ}$ since the sown (rarely until the $14^{\circ}$ day) one of them is pinnate, the other bipinnate. Generally since the $14^{\circ}$ day, the apex produces eophylls bipinnate and alternate.

Of the 50 seeds sown in the 10 pots, at the end of the experiment, persisted 6 pots with all the plants generally well developed, each one having 1 - 3 eophyllas (60\%). In other 4 pots only 4 seedlings developed, having 2 - 4 eophylls each one (32\%). Thus, of 50 seeds that have being sown, 46 germinated and seedlings developed until the end of the experiment until the $25^{\circ}$ day, in consequence, the $92 \%$ of the seedlings survived.

The $9^{\circ}$ day since the sown 30 seedlings had protophylls (60\% of the sown seeds) and 13 seedlings had the cotyledons emerging which were covered or not by the teguments, 


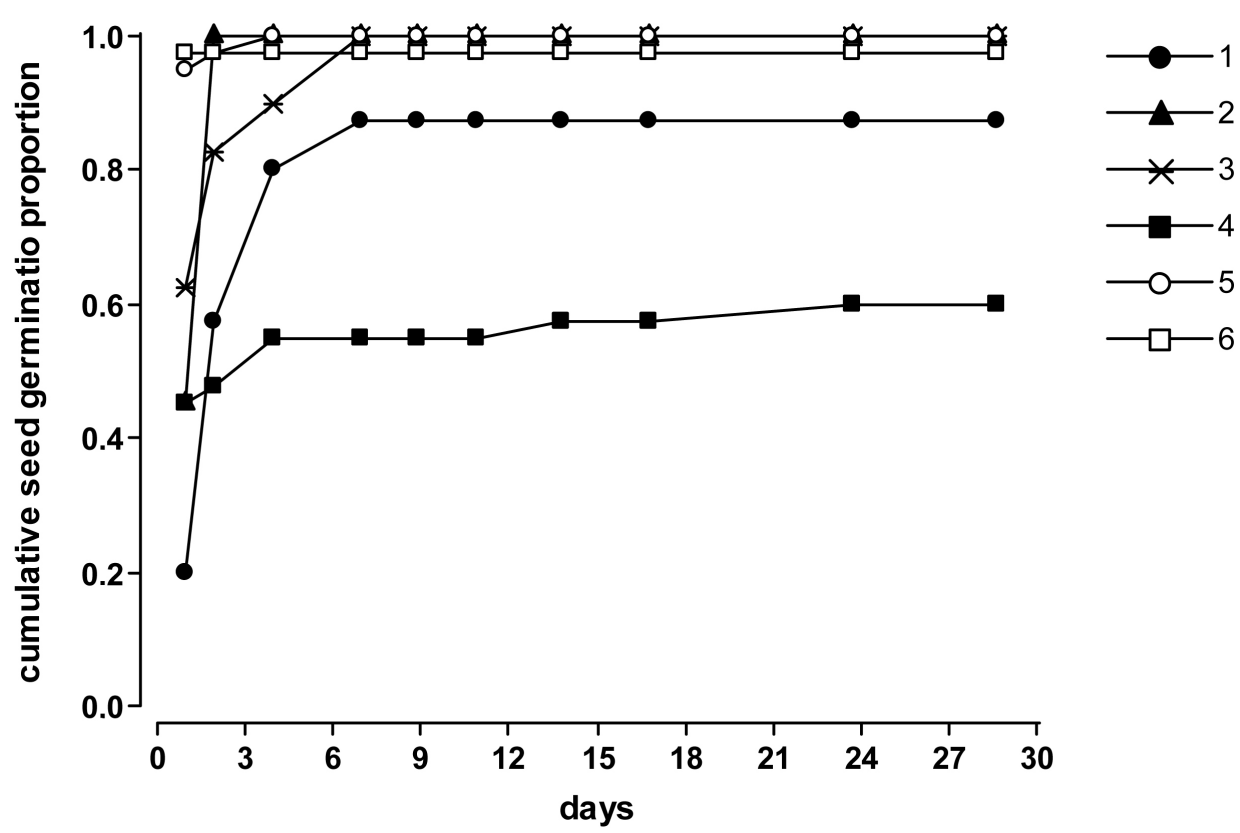

Figure 9. Mean time to germination (MTG) (mean + standard error) for each scarification treatment. Black circle $=$ treatment 1 ; triangle $=$ treatment 2 ; cross $=$ treatment 3 ; black square $=$ treatment 4 ; white circle $=$ treatment 5 ; white square $=$ treatment 6.

Table 12. Values of velocity of germination for each treatment.

\begin{tabular}{cccccc}
\hline Treatment & N samples & Mean & $\boldsymbol{\delta}$ & Minimum & Maximum \\
\hline 1 & 4 & 116.2 & 0.37 & 115.78 & 116.67 \\
2 & 4 & 117.45 & 0.33 & 117.2 & 117.9 \\
3 & 4 & 116.88 & 0.64 & 116.2 & 117.6 \\
4 & 4 & 114.68 & 3.96 & 109.78 & 118 \\
5 & 4 & 117.9 & 0.14 & 117.7 & 118 \\
6 & 4 & 118 & 0 & 118 & 118 \\
\hline
\end{tabular}

this means that the $86 \%$ of the seedlings were developing (Table 13).

Past 17 days from the beginning of the experiment, it was recorded 44 seedlings (88\%), of them, 4 exposed the cotyledons, 20 exposed the protophylls and 20 had one eophyll (rarely 2) (Table 14).

At the end of the experiment (25 after the sown), 46 seedlings survived (92\%), 5 with protophylls and 41 with eophylls ( 2 - 3, rarely 1), having being reduced in a $4 \%$ the number of seedlings achieved from the beginning (Table 15).

\subsection{Description of the Seedlings}

As germination is epigeal, the hypocotyl emerges curved like an inverted $\mathrm{U}$, then turns vertical, the cotyledons persist inside the teguments. The root is unbranched until the two protophylls develop completely; the secondary roots start to develop in accordance 
Table 13. Development of the seedlings at 9 days since the sown.

\begin{tabular}{ccc}
\hline Pot & $\mathrm{N}^{\bullet}$ seedlings with cotyledons & $\mathrm{N}^{\bullet}$ seedlings with protophylls \\
\hline 1 & 1 & 4 \\
2 & 0 & 4 \\
3 & 2 & 3 \\
4 & 1 & 4 \\
5 & 2 & 3 \\
6 & 3 & 1 \\
7 & 3 & 2 \\
8 & 1 & 1 \\
9 & 0 & 4 \\
10 & 0 & 4 \\
Total & 13 & 30 \\
\hline
\end{tabular}

Table 14. Development of the seedlings until the $17^{\circ}$ day since the sown. $\left({ }^{*}\right) n^{\circ}$ of eophylls.

\begin{tabular}{cccc}
\hline Pot & $\begin{array}{c}\mathbf{N}^{\bullet} \text { seedlings with } \\
\text { cotyledons }\end{array}$ & $\begin{array}{c}\mathbf{N}^{\bullet} \text { seedlings with } \\
\text { protophylls }\end{array}$ & $\begin{array}{c}\mathbf{N}^{\bullet} \text { seedlings with } \\
\text { eophylls }\end{array}$ \\
\hline 1 & 1 & 0 & $4^{*}$ \\
2 & 0 & 1 & $4^{*}$ \\
3 & 0 & 4 & 0 \\
4 & 0 & 3 & $2^{*}$ \\
5 & 0 & 2 & $2^{*}$ \\
6 & 3 & 2 & 0 \\
7 & 0 & 3 & $2^{* *}$ \\
8 & 0 & 4 & 0 \\
9 & 0 & 3 & $2^{* *}$ \\
10 & 0 & 0 & $4^{*}$ \\
Total & 4 & 20 & 20 \\
\hline
\end{tabular}

with the development of the eophylls and at $8-10 \mathrm{~mm}$ from the neck.

The cotyledons, when emerges, have $9-10 \mathrm{~mm}$ long $\times 7-8 \mathrm{~mm}$ lat., folded, erect, parallel to the axis, with an divergence angle of $30^{\circ}$, fleshy, ovate in shape, with smooth margins, apex rounded, sagittated in the base; between them emerges a folded protophyll.

Two sub-opposite protophylls, dark green, are developing simultaneously. One protophyll pinnate, with linear stipules 1.2 - $1.5 \mathrm{~mm}$ long., petiolate, rachis $21 \mathrm{~mm}$ long., with 4 pairs of opposite and petiolulate leaflets, oblong or elliptic in shape, asymmetric, of $7-8 \mathrm{~mm}$ long. $\times 3-4 \mathrm{~mm}$ lat., apex and base rounded. The other protophyll is bipinnate, petiolate, pinnae petiolate with 4 pairs of opposite leaflets, rachis briefly 
Table 15. Development of the seedlings at 25 days. $\left(^{*}\right) n^{\circ}$ of eophylls.

\begin{tabular}{ccc}
\hline Pot & $\mathbf{N}^{\bullet}$ seedlings with protophylls & $\mathbf{N}^{\bullet}$ seedlings with eophylls \\
\hline 1 & 1 & $4^{* *}$ \\
2 & 0 & $5^{*}$ (miniaturized) \\
3 & 0 & $4^{* *}$ \\
4 & 0 & $5\left(1^{* * *}, 3^{* *}, 1^{*}\right)$ \\
5 & 0 & $4^{* * * *}$ \\
6 & 4 & $1^{* *}$ \\
7 & 0 & $\left(1^{* * *}, 1^{* *}, 3^{*}\right)$ \\
8 & 0 & $4^{* * *}($ miniaturized $)$ \\
9 & 0 & $5^{* * *}$ \\
10 & 0 & $4^{* *}$ \\
Total & 5 & 41 \\
\hline
\end{tabular}

prolonged; petiolules $2 \mathrm{~mm}$ long., rachis $10-12 \mathrm{~mm}$ long. The leaflets have 3 - $5 \mathrm{~mm}$ long. $\times 2-4 \mathrm{~mm}$ lat., each pair unequal (one of them half measures), oblong in shape, asymmetrical, apex acute.

The eophylls, 1 - 3, are bipinnate, the first with the basal pinna petiolate, rachis 13 mm long., 4 pairs of leaflets $12-13 \mathrm{~mm}$ long. $\times 7-8 \mathrm{~mm}$ lat., the basal asymmetric; second pinna with a petiole $3 \mathrm{~mm}$ long., rachis $10 \mathrm{~mm}$ long, with 4 pairs of leaflets, the basal ones asymmetric. Apical eophylls bipinnate, pale green, each pinna with 3 pairs of leaflets, rachis briefly prolonged; first pair of leaflets asymmetrical, the others similar between each other, leaflets obovate or circular in shape, $10-15 \mathrm{~mm}$ long. $\times 7-9 \mathrm{~mm}$ lat., strongly asymmetric, half of a leaflet with rounded base, the other tightly cuneate (Figure 10).

Summarizing, it can be observed:

- Two protophylls subopposite are observed, one pinnate, the other bipinnate, dark green in color, with narrow, generally oblong leaflets, asymmetrical in the base, first vascular bundle eccentric.

- The eophylls are bippinnate, and the leaflets are obovate in shape, sometimes rounded, with the blade broader tan the blades of the protophylls and light green, with eccentric primary vascular bundle, the lateral ones conspicuous in the hemi-limb more developed. Blade rounded at the base of the hemi-limb more developed, cuneate in the other one.

\section{Discussion}

It has been suggested that the orthodox character should be ancestral and has been lost gradually favouring the installation of the recalcitrant seeds [8] [9]. The orthodox character constitutes clearly an adaptive advantage in xeric environments or in those areas with a dry season owing to the resistance to the scarce moist of the soil. Other authors 

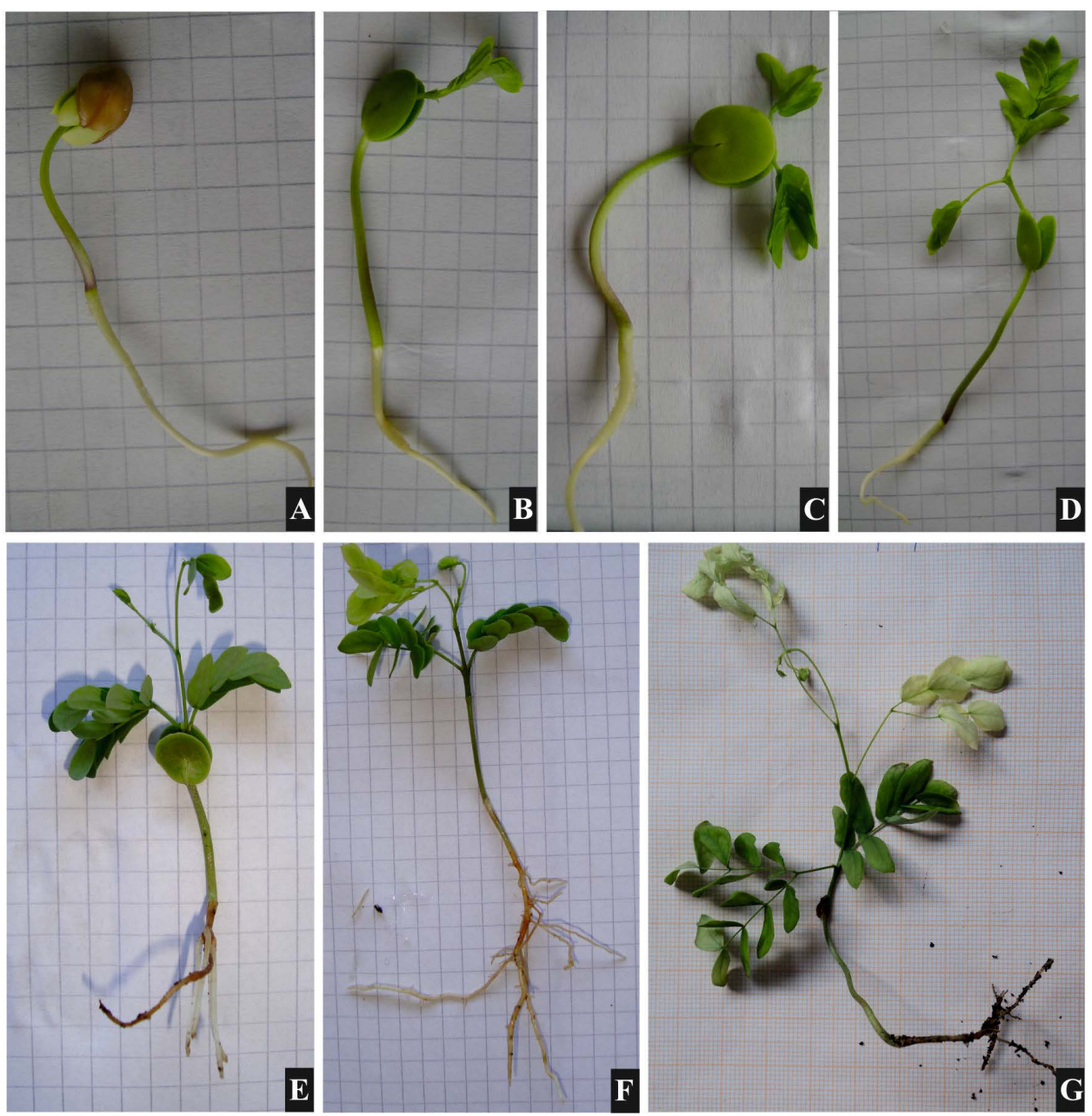

Figure 10. (A) seedling, cotyledons still inside the teguments; (B) cotyledons emerged and incipient protophylls developing; (C) two sub-opposite protophylls emerging between the cotyledons; (D) epicotyl and protophylls developed, one of the protophylls pinnate, the other bipinnate; (E) first eophyll developing; (F) two eophylls developed and different from the protophylls; (G) view of some eophylls.

points out that the orthodox character confers resistance to the predation [16].

When were described many seedlings of Leguminosae in order to solve taxonomical problems [11], the authors followed the commonly used teminology [12], distinguishing 4 categories taking into account if the germination is epigeal (phaneroepigeal, with photosynthesing cotyledons reservant or not), hypogeal (cryptohypogeal with the cotyledons reservant arising at the level of soil or below of this) placing the seedlings of Mimosoideae and Caesalpinoideae with an epigeal germination with photosynthesinzing cotyledons not reservant.

The results of this work agree with a previous contribution [6], because the germination of Chloroleucon chacöense is epigeal, phanerocotyledonar, with photosynthesizing cotyledons, the seedlings have two subopposite protophylls (one pinnate, the other bipinnate) and two or more eophylls bipinnate. 
It has been stated three categories of seeds: 1) recalcitrant, 2) orthodox and 3) intermediate [8], in which should be included the seeds of $C$. chacöense, because remain in latency until the rainy station start.

The results obtained here allow stating that until the 24 hours after the moistening of seeds previously treated, is optimum to obtain an effective \% of germination owing to their anatomical structure, adapted to persist in the soil for a long time owing to the adaptation to the environment in which the plants grow.

The results of the experiments carried one show that the seeds of $C$. chacöense can germinate with a high efficiency when are imbibited $36 \mathrm{~h}$ in water before the sown, reaching similar \% than those treated with sand paper and sulphuric acid, which verify that the teguments are nor hard neither rain tight as the seeds of $C$. tenuiflorum which need mechanical or chemical scarification to germinate. These results are corroborated by the development of seedlings in a high percentage (92\%) after the germination of seeds that did not receive treatments of scarification. Also, it is interesting to observe that the seeds of the control have had a high germination proportion $(88 \%)$.

Comparing with Chloroleucon tenuiflorum, the fruits of $C$. chacöense do not form an spiral, barely reach $360^{\circ}$, are highly predated, besides; in C. tenuiflorum, more than one fruit/inflorescence is produced, in consequence, the productivity is higher. The seeds of $C$. chacöense easily germinate when are immersed in water, because of its tegument is thin, instead the seeds of $C$. tenuiflorum germinate easily when are scarified with sand paper or sulphuric acid, surely this difference is ought to the endomorphology of the tegument undoubtedly the thickness of the teguments protect the embryo and act as a regulator of the impact of the agents that scarify. More one, the seeds of Chloroleucon chacöense lose their germinability when are treated with warm water, perhaps because it affect the embryo, while in the other species the warm water favors the germination although slower than the other treatments. By other hand, the scarified seeds increase their weight more than the no scarified, as the Baskin Index show. The results of the ANOVA of Proportion of germinates seeds and the MTG show that the treatments with cold water, sand paper and sulphuric acid allow the seeds to germinate till $24 \mathrm{~h}$ since the sown. The results of the " $\mathrm{t}$ " test show that the no scarified seeds exhibit high difference of weight only at $24 \mathrm{~h} \cdot \mathrm{s}$ since the sown. Perhaps the seeds need that lapse of time to imbibe and start the germination. It was recorded that between the unhealthy seeds, those with arrested development constitute a high percentage, perhaps some problems in the reproductive system exist.

\section{Conclusion}

It should be taken into account that in Choloreucon chacöense the \% of development of the seedlings in the laboratory is higher than in the natural habitat, thus more studies are needed in order to elucidate if the scarce density of plants should be assigned to the reduced environmental area (soil lateritic), problems in the reproductive system that produces few fruits, the high predation by herbivorous and the \% of non-viable seeds, trying to explore other localities. Perhaps the inclusion of this species in the RED 
BOOK requires these studies.

\section{Acknowledgements}

The authors wish to thank to the Universidad National of Salta (Argentina) for the grant CIUNSA N² 2099 (2012-2016).

\section{References}

[1] Barneby, R.C. and Grimes, J.W. (1996) Silk Tree, Guanacaste, Monkey’s Earring. A Generic System for the Synandrous Mimosaceae of the Americas. Part I, Abarema, Albizia and Allies. Memoirs of the New York Botanical Garden, 74, 1-292.

[2] Cabrera, A.L. (1994) Regiones fitogeográficas argentinas. Enciclopedia Argentina de Agricultura y Jardinería, Tomo II, fascículo 1. Buenos Aires, Acme.

[3] Legname, P.R. (1982) Arboles indígenas del Noroeste Argentino. Opera Lilloana, 34, 45-46.

[4] Hoc, P.S. (1981) Pithecellobium en la Argentina. Darwiniana , 23, 523-558.

[5] Hoc, P.S. (2005) Tribu VIII. Ingeae. In: Anton, A.M. and Zuloaga, F.O., Eds., Flora Fanerogámica Argentina, Fascículo 93, 128. Fabaceae, parte 14, Subfam. II. Mimosoideae, parte 5, pags. 1-26. Córdoba, PROFLORA-CONICET.

[6] Zapater, M.A., Hoc, P.S., Flores, M.C., Mamani, C.M., Lozano, E.C., Gil, M.N. and Suhring, S.S. (2016) Chloroleucon tenuiflorum (Leguminosae, Ingeae): Morphometry of Fruits, Seeds and Seedlings, Healthy and Germinability. Global Journal of Biology, Agriculture and Health Sciences, 5, 95-106.

[7] Prado, D. (1998) Chloroleucon chacöense. The IUCN Red List of Threatened Species 1998: 6570A10006310.

[8] Farnsworth, E. (2000) The Ecology and Physiology of Viviparous and Recalcitrant Seeds. Annual Review of Ecology, Evolution, and Systematics, 31, 107-138.

[9] Garwood, N.C. (1983) Seed Germination in a Seasonal Tropical Forest in Panama: A Community Study. Ecological Monographs, 53, 159-181. https://doi.org/10.2307/1942493

[10] Pammenter, N.W. and Berjak, P. (2000) Some Thoughts on the Evolution and Ecology of Recalcitrant Seeds. Plant Species Biology, 15, 153-156. https://doi.org/10.1046/j.1442-1984.2000.00035.x

[11] Gurgel, C., Moreira dos Santos, J.U., Araújo Lucas, F.C. and do Carmo Bastos, M.N. (2012) Morfologia de plântulas de Leguminosae e o potencial sistemático. Rodriguésia, 63, No. 1. https://doi.org/10.1590/S2175-78602012000100006

[12] Duke, J.A. and Polhill, R.M. (1981) Seedlings of Leguminosae. In: Polhill, R.M. and Raven, P.H., Eds., Advances in Legumes Systematics, Royal Botanic Gardens, Kew Part 1, 941-949.

[13] Nadir, A. and Chafatinos, T. (1990) Los suelos del N.O.A. (Salta y Jujuy), Tomos 1, 2, 3. Salta, Universidad Nacional de Salta.

[14] Baskin, J.M., Davis, B., Baskin, C.C., Gleason, S. and Cordell, S. (2004) Physical Dormancy Seeds of Dodonaea viscosa (Sapindales, Sapindaceae) from Hawai. Seed Science Research, 14, 81-90. https://doi.org/10.1079/SSR2003157

[15] Statistics Calculator, El Imperio de los Números-Herramientas potentes de matemáticas para todos. Electronic document. Retrieved from: El Imperio de los NúmerosHerramientas potentes de matemáticas para todos (Google+, 2016).

[16] Di Rienzo, J.A., Casanoves, F., Balzarini, M.G., Gonzalez, I., Tablada, M. and Robledo, C.W. (2014) InfoStat Versión 2014. Grupo InfoStat, FCA, Universidad Nacioonal de Córdoba. 
[17] Pritchard, H.W. and Miller, A.P. (1995) The Effects of Constants Temperatures, Light and Seed Quality on the Germination Characteristics of Agave Americana. Bol. Soc. Bot. México, 57, 11-14.

[18] Daws, M.I., Garwood, N.C. and Pritchard, H.W. (2005) Traits of Recalcitrant Seeds in a Semi-Deciduous Tropical Forest in Panamá: Some Ecological Implications. Ecology, 19, 874-885.

Submit or recommend next manuscript to OALib Journal and we will provide best service for you:

- Publication frequency: Monthly

- 9 subject areas of science, technology and medicine

- Fair and rigorous peer-review system

- Fast publication process

- Article promotion in various social networking sites (LinkedIn, Facebook, Twitter, etc.)

- Maximum dissemination of your research work

Submit Your Paper Online: Click Here to Submit

Or Contact service@oalib.com 